\title{
TANGGAPAN MASYARAKAT PANTAI LICIN SEBAGAI DAERAH TUJUAN WISATA DI DESA LEBAKHARJO KECAMATAN AMPELGADING, MALANG
}

\author{
Dicky Arinta ${ }^{1}$ I Komang Astina ${ }^{2}$, Johanis Paluin $\mathbf{B}^{\mathbf{3}}$
}

Email: dickyarinta.b@gmail.com, komang.astina.fis@um.ac.id

\begin{abstract}
Abstrak: Sektor pariwisata Provinsi Jawa Timur merupakan salah satu andalan untuk meningkatkan perekonomian. Provinsi Jawa Timur mulai mencoba memperkenalkan progam Visit East Java untuk memperkenalkan objek wisata yang berada di Jawa Timur. Kabupaten Malang merupakan salah satu kabupaten yang mengikuti program Visit East. Pantai Licin termasuk dalam kategori pantai yang akan dikembangkan oleh pemerintah kabupaten. Penelitian ini bermanfaat untuk (1) informasi untuk mendukung perencanaan pengembangan objek wisata Pantai Licin (2) informasi tentang adanya potensi pantai yang belum dikembangkan dan diharapkan adanya partisipasi masyarakat dalam mendukung pengembangan objek wisata Pantai Licin. Jenis penelitian ini adalah survei. Subyek penelitian ini adalah masyarakat Pantai Licin. Data tanggapan digunakan untuk mengetahui kesiapan masyarakat apabila Pantai Licin dijadikan sebagai objek wisata. Populasi penelitian sebanyak 30 orang. Analisis data menggunakan statistik deskriptif, yaitu scoring dan tabulasi. Berdasarkan hasil analisis, diperoleh kondisi non-fisik yang meliputi tanggapan masyarakat tergolong setuju apabila Pantai Licin dijadikan sebagai objek wisata.
\end{abstract}

Kata Kunci: Tanggapan, Pantai Licin.

\section{PENDAHULUAN}

Sektor pariwisata Provinsi Jawa Timur merupakan salah satu andalan untuk meningkatkan perekonomian. Menurut Badan Perencanaan dan Pembangunan Daerah Jawa Timur, angka kunjungan wisata pada tahun 2010 mencapai 24 juta wisatawan, baik wisatawan dari dalam maupun luar negeri. Angka tersebut terus meningkat dengan pertumbuhan sekitar 10\% per tahun (Bappeda Jawa Timur, 2010). Berdasarkan data tersebut maka Provinsi Jawa Timur mulai mencoba memperkenalkan progam Visit East Java untuk memperkenalkan objek wisata yang berada di Jawa Timur (www.jawatimuran.wordpress.com).

Kabupaten Malang merupakan salah satu kabupaten yang mengikuti program Visit East Java untuk memperkenalkan objek wisata. Objek wisata pantai andalan Kabupaten Malang kebanyakan adalah pantai. Objek wisata Kabupaten Malang yang menjadi andalan diantaranya Pantai Balekambang, Pantai Ngliyep, Pantai Goa Cina (http://issuu.com/mp-post/docs/ mp0508/13). Hal ini dikarenakan pariwisata Kabupaten Malang tersebar sesuai dengan potensi geografis. Batas sisi selatan kabupaten yang berbatasan lang- 
sung dengan pantai selatan Pulau Jawa merupakan salah satu faktor potensi. Deretan pantai di selatan Kabupaten Malang sangat beragam mulai dari ujung timur sampai barat, meliputi Pantai Licin, Sipelot, Lenggoksono, Tambakasri, Tamban, Sendang Biru, Bajul Mati, Balekambang, Kondang Merak, Ngliyep, Jonggring Saloko, Mondangan (Rencana Tata Ruang Wilayah Kabupaten Malang, 2010).

Pantai Licin terletak di Dusun Licin, Desa Lebakharjo, Kecamatan Ampelgading. Pantai ini memiliki karang yang cukup besar. Pantai Licin memiliki keunikan dari pantai lainnya karena pasir pantai berwarna hitam yang merupakan hasil sedimentasi dari gunung Semeru yang bermuara di sisi Selatan Samudra Hindia. Keunikan lain dari Pantai Licin adalah pada saat perjalanan menuju lokasi dapat melihat jalur lahar dingin dari Gunung Semeru. Pantai ini belum banyak diketahui wisatawan umum sehingga masih alami. Potensi yang dimiliki serta perjalanan yang sangat menantang menyebabkan pantai ini banyak dikunjungi oleh wisatawan khususnya pecinta alam. Pantai Licin termasuk dalam kategori pantai yang akan dikembangkan oleh pemerintah kabupaten. Pengembangan ini terdapat dalam rencana tata ruang wilayah Kabupaten Malang Tahun 2010. Pengembangan pantai memerlukan tanggapan dari masyarakat untuk mengetahui kesiapan masyarakat apabila pantai Licin dijadikan sebagai daerah tujuan wisata. Tanggapan merupakan dasar pembentukan sikap dan perilaku. Tanggapan individu terhadap lingkungannya merupakan faktor penting karena akan berlanjut dalam menentukan tindakan indi- vidu tersebut. Tanggapan masyarakat adalah suatu proses pembentukan kesan, pendapat, ataupun perasaan terhadap sesuatu hal yang melibatkan penggunaan informasi secara terarah Ritohardoyo, 2006 dalam Akbar (2012). Berdasarkan uraian di atas maka peneliti ingin mengetahui tanggapan masyarakat apabila Pantai Licin dijadikan sebagai daerah objek wisata.

\section{METODE}

Penelitian ini menggunakan metode survey dengan pengambilan data berupa kuisoner. Data mengenai tanggapan masyarakat Pantai Licin dilakukan dengan memberikan kuesioner kepada masyarakat sebagai responden. Populasi dari penelitian ini sebanyak 30 orang karena jumlah tersebut adalah orang yang aktif dalam pengelolahan Pantai Licin. Teknik pengambilan sampel untuk menentukan wisatawan menggunakan metode Quota Sampling dengan cara aksidental, yaitu teknik pengambilan sampel dengan cara memilih sampel dari populasi sampel yang mengelolah obyek wisata Pantai Licin dan mengambil siapa saja yang ditemui di obyek wisata tersebut. Data sekunder yang digunakan dalam penelitian ini adalah Peta Rupa Bumi Pantai Licin. Analisa data yang digunakan adalah scoring dan tabulasi tunggal selanjutnya dilakukan analisa deskriptif.

\section{HASIL}

\section{Tanggapan Masyarakat Pantai Licin}

Tanggapan masyarakat pada penelitian ini diketahui melalui kuisioner 
Dicky Arinta, I Komang Astina, Johanis Paluin B. Persepsi Masyarakat Pantai Licin

Sebagai Daerah Tujuan Wisata Di Desa Lebakharjo Kecamatan Ampelgading, Malang

dengan menggunakan skala Linkert dapat dilihat pada tabel 1. berikut:

Tabel 1. Hasil kuisioner tanggapan masyarakat Pantai Licin kategori pengetahuan

\begin{tabular}{|c|c|c|c|c|c|c|c|c|c|c|c|c|}
\hline \multirow[t]{3}{*}{ No } & \multirow[t]{3}{*}{ Pertanyaan } & \multicolumn{8}{|c|}{ Tanggapan masyarakat berdasarkan pengetahuan } & \multirow[t]{3}{*}{$\mathbf{N}$} & \multirow[t]{3}{*}{ Skor } & \multirow[t]{3}{*}{$\%$} \\
\hline & & \multicolumn{2}{|c|}{4} & \multicolumn{2}{|l|}{3} & \multicolumn{2}{|l|}{2} & \multicolumn{2}{|l|}{1} & & & \\
\hline & & $\mathrm{F}$ & $\%$ & $\mathrm{~F}$ & $\%$ & $\mathrm{~F}$ & $\%$ & $\mathrm{~F}$ & $\%$ & & & \\
\hline 1 & $\begin{array}{l}\text { Menurut anda apa } \\
\text { keunikan Pantai Licin? }\end{array}$ & 25 & 83 & 5 & 17 & 0 & 0 & 0 & 0 & 30 & 115 & 96 \\
\hline 2 & $\begin{array}{l}\text { Apa anda mengetahui } \\
\text { Pantai Licin akan di- } \\
\text { jadikan daerah tujuan } \\
\text { wisata? }\end{array}$ & 0 & 0 & 30 & 100 & 0 & 0 & 0 & 0 & 30 & 90 & 75 \\
\hline 3 & $\begin{array}{l}\text { Menurut anda, Apa } \\
\text { yang perlu dikem- } \\
\text { bangkan agar Pantai } \\
\text { Licin menjadi daerah } \\
\text { tujuan wisata? }\end{array}$ & 30 & 100 & 0 & 0 & 0 & 0 & 0 & 0 & 30 & 120 & 100 \\
\hline 4 & $\begin{array}{l}\text { Apa anda mengetahui } \\
\text { tujuan wisatawan yang } \\
\text { datang ke Pantai } \\
\text { Licin? }\end{array}$ & 3 & 10 & 27 & 90 & 0 & 0 & 0 & 0 & 30 & 93 & 78 \\
\hline \multirow[t]{3}{*}{5} & $\begin{array}{l}\text { Apakah anda menge- } \\
\text { tahui dengan siapa } \\
\text { wisatawan berkunjung } \\
\text { ke Pantai Licin? }\end{array}$ & 9 & 30 & 12 & 40 & 1 & 3 & 8 & 27 & 30 & 82 & 68 \\
\hline & & \multicolumn{8}{|c|}{ Jumlah nilai } & & \multicolumn{2}{|l|}{500} \\
\hline & & \multicolumn{8}{|c|}{ Rata-rata nilai } & & 100 & \\
\hline
\end{tabular}

Berdasarkan rata-rata nilai hasil kuisioner diketahui bahwa tanggapan masyarakat Pantai Licin kategori pengetahuan sangat setuju untuk dijadikan sebagai daerah tujuan wisata. Nilai tertinggi didapatkan dari pertanyaan nomor tiga yang menanyakan tentang fasilitas yang perlu dibangun di Pantai Licin. Nilai terendah didapat dari pertanyaaan nomor lima yang menanyakan dengan siapa wisatawan berkunjung. 
Tabel 2. Hasil kuisioner tanggapan masyarakat Pantai Licin kategori sikap

\begin{tabular}{|c|c|c|c|c|c|c|c|c|c|c|c|c|}
\hline \multirow[t]{3}{*}{ No } & \multirow[t]{3}{*}{ Pertanyaan } & \multicolumn{8}{|c|}{ Tanggapan masyarakat berdasarkan sikap } & \multirow[t]{3}{*}{$\mathbf{N}$} & \multirow[t]{3}{*}{ Skor } & \multirow[t]{3}{*}{$\%$} \\
\hline & & \multicolumn{2}{|l|}{4} & \multicolumn{2}{|l|}{3} & \multicolumn{2}{|l|}{2} & \multicolumn{2}{|l|}{1} & & & \\
\hline & & $\mathrm{F}$ & $\%$ & $\mathrm{~F}$ & $\%$ & $\mathrm{~F}$ & $\%$ & $\mathrm{~F}$ & $\%$ & & & \\
\hline 6 & $\begin{array}{l}\text { Apakah anda setuju jika Pantai } \\
\text { Licin dijadikan daerah tujuan } \\
\text { wisata? }\end{array}$ & 30 & 100 & 0 & 0 & 0 & 0 & 0 & 0 & 30 & 120 & 100 \\
\hline 7 & $\begin{array}{l}\text { Pantai Licin merupakan pantai yang } \\
\text { dikelolah oleh Perhutani, sehub- } \\
\text { ungan dengan adanya pengem- } \\
\text { bangan Pantai Licin yang akan di- } \\
\text { jadikan sebagai daerah tujuan } \\
\text { wisata. Apakah anda setuju pengel- } \\
\text { olahan Pantai Licin diserahkan ke } \\
\text { masyarakat? }\end{array}$ & 0 & 0 & 17 & 57 & 13 & 43 & 0 & 0 & 30 & 77 & 64 \\
\hline 8 & $\begin{array}{l}\text { Jika masyarakat dapat berpartisipasi } \\
\text { dalam pengolahan Pantai Licin, } \\
\text { apakah anda setuju jika pemerintah } \\
\text { masih ikut dalam pengelolahan pan- } \\
\text { tai tersebut? }\end{array}$ & 0 & 0 & 20 & 67 & 9 & 30 & 1 & 3 & 30 & 79 & 66 \\
\hline 9 & $\begin{array}{l}\text { Apakah anda setuju jika peran } \\
\text { pemerintah hanya memberi bantuan } \\
\text { untuk pembangunan Pantai Licin? }\end{array}$ & 30 & 100 & 0 & 0 & 0 & 0 & 0 & 0 & 30 & 120 & 100 \\
\hline \multirow[t]{3}{*}{10} & $\begin{array}{l}\text { Apabila pemerintah tidak memberi } \\
\text { bantuan untuk pembangunan Pantai } \\
\text { Licin, apakah anda setuju untuk } \\
\text { melakukan swadaya untuk men- } \\
\text { jadikan Pantai Licin sebagai daerah } \\
\text { tujuan wisata? }\end{array}$ & 0 & 0 & 23 & 77 & 7 & 23 & 0 & 0 & 30 & 83 & 69 \\
\hline & & \multicolumn{8}{|c|}{ Jumlah nilai } & & \multicolumn{2}{|l|}{479} \\
\hline & & \multicolumn{8}{|c|}{ Rata-rata nilai } & & 96 & \\
\hline
\end{tabular}

Berdasarkan rata-rata nilai hasil kuisioner diketahui bahwa tanggapan masyarakat Pantai Licin kategori sikap setuju untuk dijadikan sebagai daerah tujuan wisata. Nilai tertinggi didapatkan dari pertanyaan nomor enam dan sembilan yang menanyakan tentang apakah masyarakat setuju Pantai Licin dijadikan sebagai daerah tujuan wisata dan pemberian bantuan dari pemerintah untuk pembangunan Pantai Licin. Nilai terendah didapat dari pertanyaaan nomor tujuh yang menanyakan apabila pengelolaan Pantai Licin diserahkan kepada masyarakat. 
Dicky Arinta, I Komang Astina, Johanis Paluin B. Persepsi Masyarakat Pantai Licin

Sebagai Daerah Tujuan Wisata Di Desa Lebakharjo Kecamatan Ampelgading, Malang

Tabel 3. Hasil kuisioner tanggapan masyarakat Pantai Licin kategori motif bertindak

\begin{tabular}{|c|c|c|c|c|c|c|c|c|c|c|c|c|}
\hline \multirow[t]{3}{*}{ No } & \multirow[t]{3}{*}{ Pertanyaan } & \multicolumn{8}{|c|}{ Tanggapan masyarakat berdasarkan motif bertindak } & \multirow[t]{3}{*}{$\mathbf{N}$} & \multirow[t]{3}{*}{ Skor } & \multirow[t]{3}{*}{$\%$} \\
\hline & & \multicolumn{2}{|l|}{4} & \multicolumn{2}{|l|}{3} & \multicolumn{2}{|l|}{2} & \multicolumn{2}{|l|}{1} & & & \\
\hline & & $\mathrm{F}$ & $\%$ & $\mathrm{~F}$ & $\%$ & $\mathrm{~F}$ & $\%$ & $\mathrm{~F}$ & $\%$ & & & \\
\hline 11 & $\begin{array}{l}\text { Jika Pantai Licin dikem- } \\
\text { bangkan sebagai daerah } \\
\text { tujuan wisata, maka Pantai } \\
\text { Licin akan dipromosikan ke } \\
\text { masyarakat luas }\end{array}$ & 30 & 100 & 0 & 0 & 0 & 0 & 0 & 0 & 30 & 120 & 100 \\
\hline 12 & $\begin{array}{l}\text { Jika Pantai Licin sudah di- } \\
\text { promosikan, maka akan } \\
\text { banyak wisatawan yang } \\
\text { berkunjung sehingga meng- } \\
\text { ganggu kegiatan masyarakat }\end{array}$ & 0 & 0 & 30 & 100 & 0 & 0 & 0 & 0 & 30 & 90 & 75 \\
\hline 13 & $\begin{array}{l}\text { Jika wisatawan banyak yang } \\
\text { berdatangan,maka lalu lintas } \\
\text { akan ramai sehingga daerah } \\
\text { menjadi rawan dan bising }\end{array}$ & 0 & 0 & 25 & 83 & 5 & 17 & 0 & 0 & 30 & 85 & 71 \\
\hline 14 & $\begin{array}{l}\text { Apabila Pantai Licin dijadi- } \\
\text { kan daerah tujuan wisata, } \\
\text { apakah anda yakin jika } \\
\text { ekonomi masyarakat sekitar } \\
\text { akan mengalami pening- } \\
\text { katan? }\end{array}$ & 13 & 43 & 17 & 57 & 0 & 0 & 0 & 0 & 30 & 103 & 86 \\
\hline \multirow[t]{3}{*}{15} & $\begin{array}{l}\text { Apakah anda mempunyai } \\
\text { peluang untuk membuka } \\
\text { usaha baru ketika Pantai } \\
\text { Licin dijadikan sebagai dae- } \\
\text { rah tujuan wisata? }\end{array}$ & 13 & 43 & 13 & 43 & 4 & 13 & 0 & 0 & 30 & 99 & 83 \\
\hline & & \multicolumn{8}{|c|}{ Jumlah nilai } & & \multicolumn{2}{|l|}{4779} \\
\hline & & \multicolumn{8}{|c|}{ Rata-rata nilai } & & 99 & \\
\hline
\end{tabular}

Berdasarkan rata-rata nilai hasil kuisioner diketahui bahwa tanggapan masyarakat Pantai Licin kategori motif bertindak sangat setuju untuk dijadikan sebagai daerah tujuan wisata. Nilai tertinggi didapatkan dari pertanyaan nomor sebelas yang menanyakan tentang jika Pantai Licin dijadikan sebagai daerah tujuan wisata maka akan dipromosikan ke masyarakat. Nilai terendah didapat dari pertanyaaan nomor tiga belas yang menanyakan jika wisatawan banyak yang berdatangan,maka lalu lintas akan ramai sehingga daerah menjadi rawan dan bising. Secara keseluruhan bahwa tanggapan masyarakat kategori pengetahuan, sikap dan motif bertindak setuju Pantai Licin utnuk dijadikan daerah tujuan wisata.

\section{PEMBAHASAN}

\section{Tanggapan Masyarakat Pantai Licin}

Tanggapan adalah ingatan seseorang setelah selesai mengamati. Menurut Ahmadi (1998:64) tanggapan diartikan sebagai gambaran ingatan dari pengamatan di mana objek yang diamati tidak lagi 
berada dalam ruang dan waktu pengamatan. Menurut Madjda dalam Komalasari dan Wirawan (2010), tanggapan dipengaruhi oleh beberapa faktor, yaitu:

1) Faktor yang ada pada diri seseorang berupa dorongan untuk melakukan aktifitas karena keinginannya sendiri atau sesuatu yang diharapkan dari apa yang dilakukan, didengar dan dilihatnya.

2) Faktor dari luar, yaitu apa yang di lihat dan didengar, apabila seseorang mulai merasakan bahwa apa yang dilihat dan didengar itu tidak membawanya pada sesuatu yang diharapkan. Maka hal itu tidak akan menarik perhatiannya, tetapi sebaliknya bila seseorang sudah mulai merasakan apa yang dilihat dan didengarnya akan membawa sesuatu yang diharapkan maka akan menarik perhatiannya. Berdasarkan faktor tersebut tanggapan masyarakat dikategorikan menjadi tiga, yaitu: pengetahuan, sikap dan motif bertindak.

Tanggapan masyarakat berdasarkan kategori pengetahuan sangat setuju Pantai Licin dijadikan daerah wisata karena berdasarkan wawancara dengan masyarakat, Pantai Licin memiliki panorama yang cukup indah akan tetapi kurangnya sarana dan prasarana serta sulitnya aksesbilitas yang masih menjadi kendala dari pengembangan sedangkan Pantai Licin mulai ramai dikunjungi wisatawan. Sulitnya aksesbilitas sangat mempengaruhi keterjangkauan dari Pantai Licin. aksesibilitas berarti kemudahan melakukan pergerakan di antara dua tempat. (Blunden dan Black, 1984).

Pantai Licin digunakan untuk berpiknik dan menikmati pemandangan khususnya pada saat hari libur biasanya wisatawan yang datang ke pantai Licin kebanyakan lebih banyak berkelompok daripada datang berdua dengan teman.

Tanggapan masyarakat berdasarkan kategori sikap setuju Pantai Licin dijadikan daerah wisata meskipun hanya ada sedikit bantuan dari pemerintah yaitu berupa pembangunan tandon air. Masyarakat Pantai Licin melakukan iuran tiap bulannya Rp 5.000,00 per kepala keluarga. Selain itu berdasarkan hasil wawancara dengan masyarakat Pantai Licin, sebagaian masyarakat Pantai Licin yang sebagian berprofesi sebagai nelayan dan petani menyebabkan kondisi perekonomiannnya menengah ke bawah merupakan salah satu alasan masyarakat untuk menjadikan pantai Licin sebagai objek wisata.

Tanggapan masyarakat berdasarkan kategori motif bertindak sangat setuju Pantai Licin dijadikan daerah wisata. Berdasarakan hasil wawancara dengan masyarakat, Pantai Licin ini dikembangkan menjadi objek wisata dan diharapkan banyak dikunjungi wisatawan sehingga ada peluang usaha baru untuk menambah pendapatan masyarakat. Andayani dan Rusli (2012), menjelaskan pembukaan pariwisata akan meningkatkan peran beberapa sektor pendukung seperti biro perjalanan wisata, industri kerajinan atau cinderamata, obyek dan daya tarik wisata, hotel dan restoran sehingga mendukung terjadinya pembangunan

Masyarakat Pantai Licin mempunyai cara untuk mempromosikan dengan cara mencetak brosur serta banner kemudian dibagikan kepada desa terdekat untuk diketahui masyarakat luar serta mengadakan acara pertunjukan seni seperti orkes dangdut setiap setahun sekali pada saat 
Dicky Arinta, I Komang Astina, Johanis Paluin B. Persepsi Masyarakat Pantai Licin Sebagai Daerah Tujuan Wisata Di Desa Lebakharjo Kecamatan Ampelgading, Malang

hari raya, dan upacara satu suro. Promosi hanya dapat dilakukan dengan menyebarkan brosur karena keterbatasan dana. Andayani dan Rusli (2012), menjelaskan pariwisata akan meningkatkan peran beberapa sektor pendukung seperti biro perjalanan wisata, industri kerajinan atau cinderamata, obyek dan daya tarik wisata, hotel dan restoran sehingga mendukung terjadinya pembangunan.

Secara umum tanggapan masyarakat pantai Licin berdasarkan kategori pengetahuan, sikap dan motif bertindak setuju untuk dijadikan objek wisata karena Pantai Licin memiliki berbagai potensi yang belum dikembangkan seperti karang, pasir berwarna hitam serta masih alaminya daerah disekitar pantai Licin, keindahan jalur lahar dingin dari gunung Semeru. Potensi pantai inilah yang dipromosikan kepada wisatawan.

\section{KESIMPULAN DAN SARAN}

\section{Kesimpulan}

Berdasarkan kuisoner tentang tanggapan masyarakat Pantai Licin maka diperoleh hasil bahwa tanggapan masyarakat Pantai Licin untuk kategori pengetahuan $100 \%$, sikap 96\%, dan motif bertindak 99\%. Berdasarkan hasil kuisoner tersebut maka masyarakat Pantai Licin setuju apabila dijadikan sebagai objek wisata.

\section{Saran}

Diharapkan untuk peneliti selanjutnya perlu memasukkan variabel tanggapan masyarakat dalam pengembangkan objek wisata.

\section{DAFTAR PUSTAKA}

Ahmadi, Abu. 1998. Psikologi umum. Jakarta: PT Rineka Cipta.

Akbar T. Tanggapan dan Harapan Untuk Pengembangan Pariwisata Pantai Pangandaran Pasca Tsunami. (online)(https://www.google.com/u $\underline{\mathrm{rl} \text { ? } \mathrm{sa}}=\mathrm{t} \& \mathrm{rct}=\mathrm{j} \& \mathrm{q}=\& \mathrm{esrc}=\mathrm{s} \&$ source $=$ web\&cd $=1 \& c a d=$ rja \&ved $=0 \mathrm{CCo}$ QFjAA\&url=http $\% 3 \mathrm{~A} \% 2 \mathrm{~F} \% 2 \mathrm{Flib}$. geo.ugm.ac.id\%2Fojs\%2Findex.ph p\%2Fjbi\%2Farticle\%2Fdownload $\% 2 \mathrm{~F} 27 \% 2 \mathrm{~F} 27 \&$ ei=ZiynUsz5H42 WrAfh14HICQ\&usg=AFQjCNHY 2FPjp2yHNFvWZKqHgcS4ASux A\&bvm=bv.57799294,d.bmk), diakses 20 September 2013

Andayani, Rusli, Antariksa. 2012. Pengembangan Kawasan Wisata Pantai Balekambang Kabupaten Malang.(online) (https://www.google.com/url?sa=t $\& \mathrm{rct}=\mathrm{j} \& \mathrm{q}=\&$ esrc $=\mathrm{s} \&$ source $=$ web $\&$ $c d=2 \& c a d=r j a \& v e d=0$ CDUQFjAB \&url=http $\% 3 \mathrm{~A} \% 2 \mathrm{~F} \% 2$ Frekayasasi pil.ub.ac.id $\% 2$ Findex.php $\% 2$ Frs $\% 2$ Farticle $\% 2$ Fdownload $\% 2$ F217\%2F 213 \&ei=nLWnUr6GN4mMrQfhoIDw Ag\&usg=AFQjCNGI3yis5HLJbPZvpVR9AP55Qpqg\&sig 2=yu45UDXjDQF6IUykYsNxg\&b vm=bv.57799294,d.bmk), diakses 11 Juni 2013.

Bintarto, R. 1982. Metode Analisa Geografi. Jakarta: LP3ES.

Black, J. 1981. Urban Transport Planning, Theory and Practice. London: Croom Helm Ltd.

Dahuri, R. 2003. Keanekaragaman Hayati Laut, Aset Pembangunan Berkelanjutan Indonesia. Jakarta: PT Gramedia Pustaka Utama.

Dahyar, Muhammad. 1999. Penerapan Pendekatan Pengelolaan Wilayah Pesisir Terpadu dalam Pemba- 
ngunan Pariwisata di Kepulauan Derawan Provinsi Kalimantan Timur. Tesis tidak diterbitkan. Bogor: Institut Pertanian Bogor.

http://issuu.com/mp-post/docs/ mp0508/13, diakses 13 Juni 2013.

http://jawatimuran.wordpress.com/?s=visi t+east+java, diakses 13 juni 2013.

Komalasari Eva \& Wirawan Bintang. 2010. Tanggapan Masyarakat Terhadap Program Konversi Minyak Tanah Ke Lpg (Studi Pada Masyarakat Dusun Ribu-Ribu Kampung Bukit Gemuruh Kecamatan Way Tuba Kabupaten Way
Kanan). Lampung: Universitas negeri Lampung.

Yani, Ahmad. 2004. Pengembangan Instrumen Survei Awal Objek Wisata Pantai Berdasarkan Faktor Geografi. (online), (http://file.upi. edu/Direktori/FPIPS/JUR._PEND. GEOGRAFI/196708121997021AHMAD_YANI/ artikel_Pangandaran_Aktripa.pdf), diakses pada 13 Juni 2013. 